\section{MOTORIC FUNCTIONS AND COGNITION IN ELDERLY}

\author{
Stevan S. Jovanović ${ }^{1}$ \\ Dragan M. Pavlović
}

UDK: $615.851 .1: 159.964 .2: 130.1$

1 Higher Education School of Professional Health Studies

2 Faculty for special education and rehabilitation, University of Belgrade, Belgrade, Serbia

\section{FINANCIAL DISCLOSURE}

This article is partially financed by the Ministry of Science, Republic of Serbia, Project No 175033

\section{Summary}

The prolonging of a lifespan and the increasing proportion of elderly people in general population are setting new healthcare tasks. One of them is researching and clarifying the relations and links between motoric and cognitive functions in elderly. "Impoverishment" of cognitive capacities occurs during the aging process. Many studies show a strong link between cognition and the function of walking. There is growing evidence that the decline in cognitive functions is resulting in deterioration of walking. Usually described as characteristic of the later stages of dementia, the distortion of ambulation may also be present in the earlier stages, even before the prodromal stage of mild cognitive impairment. Speed and temporal and spatial variability of steps are the main gait characteristics which are connected to the degree of decline in cognitive processes. Those characteristics are motor phenotype that reflects the deterioration of cognitive performance and which can be used for prediction of dementia.

It is assumed that physical activity provides beneficial effects at cognitive and psychological levels, including prevention and improvement of depressive states and anxiety disorders, enhancing stress reduction, improved self-confidence and above all it delayes cognitive decline in the elderly. Disruption of axons and myelin in the cerebral white matter is considered one of the primary mechanisms underlying age-related cognitive decline. Therefore, maintaining white matter structural connectivity in the old age may be one of the key factors in preserving brain function and high cognitive performance necessary for independent living. Physical activity also influences cerebrovascular mechanisms, such as preserving higher blood vessel elasticity and wall integrity.

Moreover, there is an association between light physical activity and white matter integrity especially in the temporal lobe. The conclusion of some studies shows a relationship between the $\varepsilon 4$ allele and brain derived neurotrophic factor (BDNF) response to physiologic adaptation which likely impacts the extent of neuroprotective benefit gained from engagement in physical exercise. Some authors propose a program of exercises which consist of a combined aerobic and resistance training. Motoric function and cognition are closely related and using regular physical activity is important for maintaining physical and mental health in the elderly.

Keywords: locomotion, physical activity, cognition, elderly. 


\section{AGEING AND COGNITION}

During the history of human beings, reaching the old age was more the exception than the rule. In India, the impact of aging on physical and cognitive disorders and their treatment is described back in Ayurveda [1]. Experts estimate that life expectancy at a global leve, in the mid-18th century was only 25 years [2]. Today, demographers note that the aging population is expanding on global scale. In the mid 20th century life expectancy was 47 years worldwide and today it increase to 67 years but in 2050 it is expected to exceed 75 years [3].

There are two separate systems of memory: declarative/explicite that is conscious and nondeclarative or procedural/implicit memory trat is uncoscious [4]. Both types of memory change throughout the life cycle [5]. According to the hypothesis of cognitive perceptual load, mental functioning depends on cognitive tasks or needs that individuals should perform. "Impoverishment" of cognitive capacities occurs during the aging process [6]. The information degradation hypothesis claims that perceptual degradation of signal inputs caused by neurobiological processes connected with aging cause errors in the processing of perceptual information finally leading to disruption of higher order cognitive processes [7]. Reduced capacity for discrimination or differentiation stimulus causes damage in a large number of aspects of cognitive function associated with aging.

The literature cites very interesting opinion of Salthouse who believes that the "speed of processing" is the key reason for the decline of cognitive function in the aging process, including memory. According to the model of information processing, in the processes of perception, decision-making and response selection, that occure in the serial manner, the problem arrises with reduced time to perform these processes due to slow or extended time for performing thinking operations that are already supposed to be completed [8]. In addition, it is assumed that the "cascade effect" along the process may result in loss of the results of previous cognitive processes before they are brought to the finalization and integration operations with the thought that arise in the coming time of sequences [8].

\section{LINK BETWEEN LOCOMOTOR AND COGNITIVE FUNCTION IN OLD AGE}

Locomotion is described as an automatic rhythmic activity that characterizes alternative coordinated movements of crossed flexion and extension of the lower extremities [9]. It is considered to be a simple motor activity in healthy individuals because of its predominantly subcortical character. Adoption of locomotor automatisms relies on motor procedural memory which allows the gradual emergence of automated processes in healthy individuals. The automated nature of walk relies on ready-made motor programs meaning that locomotion in healthy subjects requires a minimum degree of attention and cognitive resources [10]. 
Attention is a complex multidimensional cognitive function that overlaps with executive functions and contribute to information processing. It has limitations and can be "overwhelmed" by the existence of two tasks that are performed at the same time leading to an inability to adequately perform one or both tasks [10]. Many studies show a strong link between cognitive processes and ambulation due to the fact that walking is performed in a very variable space-time conditions. There is growing evidence that a decline in cognitive functions result in deterioration of walking Impaired devided attention significantly undermines the ability of patients with Alzheimer's disease to regulate the variability of steps and leads to instability as the risk factor for falls [11]. These results support the concept that people with impaired cognitive functions are impaired in domains of attention and executive functions important for the ambulation [12].

A prospective, longitudinal observational study was conducted during the period of 6 years, on participants older than 65 years without comorbid conditions and cognitive impairment with the aim to unite all important predicting factors for the development of cognitive dysfunction [13]. The data indicated that the results of the tests of cognitive function and the volume of the hippocampus were significant predictive indicators of the occurrence of mild dementia regardless of sex and age. Test of amblatory function showed that walk is another independent risk factor which can predict the occurrence of persistent cognitive impairment [13].

One of the important preconditions for normal movement or motor function is the ability to orientate in space. It is known that the factor of aging affects this ability. In the study by Leon et al. [14], the ability of spatial memory and orientation in people of different age groups and sex, were assessed. The results showed that men were more successful in carrying out the tasks than women and that the ability of spatial memory declines with age. Usually described as characteristic in the later stages of dementia, the distortion of walking function may also be disclosed in the earlier stages, even before the prodromal stage of mild cognitive impairment [15], [16]. There are two main parameters of locomotor function which are connected to the degree of decline in cognitive processes. These are the speed and the temporal and spatial variability of steps [16].

Zimmerman et al. [17] investigated the relationship between volume and neurochemical hippocampal features with locomotor function. Their study was designed to investigate the hippocampal volume and neurochemical characteristics of the hippocampus (the ratio of $\mathrm{N}$-acetylaspartata and creatine) by magnetic resonance imaging (MRI) and proton magnetic resonance spectroscopy (MRS) as a walk quantitative features which includes stride length and duration of swinging phase during a single support. The subjects were cognitively preserved, nondemented people, average age of 81 . The results pointed to the fact that the increased variability in the length of the steps was associated with lower hippocampal metabolism, while the reduced stride length was associated with smaller hippocampal volume but not hippocampal neurochemistry [17]. 


\section{MOTOR FUNCTION AS A BIOMARKER OF COGNI- TIVE DECLINE}

Because of this prognostic heterogeneity, researchers are trying to define certain indicators or the so-called "biomarkers" that would serve for predictive purposes. Particularly interesting are the markers relating to the motor function [18]. It is concluded that placing dual tasks while walking allows the component to isolate the cognitive control of locomotion and provide insight into the mechanisms of motor control [11], [19]. The dual motor task is a task that requires divided attention during which participants perform locomotor action while performing demanding cognitive tasks (computing, or reciting etc.). Thus, it can detect latent disorders of walk that are evident only during the state that the authors refere as "cognitive stress" [20].

Montero et al. [20] conducted a study in participants aged 65 years and over with amnestic and nonamnestic mild cognitive impairment, who were able to walk without help and independently, and who did not have neurological disease with residual motor deficits or severe musculoskeletal dysfunction. These two subtypes of cognitive impairment were compared with a control group of healthy elderly. The study showed that subjects with amnestic mild cognitive impairment have reduced walking speed and increased variability in the duration of the steps in relation to people with mild nonamnestic disorder. This difference increased particularly during the performance of dual tasks. Patients with amnestic and nonamnestc cognitive impairment do have a diffe- rent "motor signature" of locomotion compared with a group of intellectually preserved persons [20]. Episodic memory relies on neural networks which include the hippocampus whose parts have a role in spatial orientation and management of movement in space [21] and has the role in locomotor function [17]. The hippocampus also provides links with basal ganglia including the corpus striatum, which plays an important role in controlling automated movements as those involved in locomotion. Neurodegenerative and microvascular changes associated with the aging process can affect the pathways and structures which reduces their functional capacity.

Several studies conclude that reduced aging-related functioning capacities can be latent and become overt only during the performance of dual tasks [20], [18]. It is obvious that assesment of motoric functions especially locomotor is a very valuable tool in predicting the onset of dementia. Of importance is also the link between cognition and locomotion in elderly people making them prone to falls as one in three persons over the age of 65 years living in their own homes, experience an accidental fail at least once a year [22].

\section{POSITIVE INFLUENCE OF PHYSICAL ACTIVITY AND EXERCISES ON COGNITION IN ELDERLY}

According to the the World Health Organization, sedentarism is considered to be a risk factor for cardiovascular and metabolic diseases and premature mortality [23]. It is assumed that physical 
activity provides beneficial effects at cognitive and psychological levels, including prevention and improvement of depressive and anxiety disorders, enhanced stress reduction, improved selfconfidence and delayes cognitive decline in the elderly.

Hippocampal and medial temporal lobe has larger volume in adults who are healthy and in good physical shape [24], [25]. The authors point out that physical activity and training stimulate hippocampal perfusion. Aerobic training increases the size of the anterior hippocampus in elderly which is accompanied by improvements in spatial memory. Also, the study has shown that the increase in the volume of the hippocampus is associated with higher levels of serum mediator of neurogenesis in the dentate gyrus. These important findings indicate that aerobic physical exercise can restore lost volume of the hippocampus in later adulthood, followed by improvement of memory function [26].

Cerebrovascular disorders such as cerebral small vessel disease with white matter lesions, and reduced white matter integrity have been linked to reduced cognitive function [27]. It has been suggested that white matter lesions and brain atrophy are strongly associated. Disruption of axons and myelin in white matter is considered one of the primary mechanisms underlying age-related cognitive decline [28], [29]. Therefore, maintaining white matter structural connectivity may be one of the key factors for preserving brain function and high cognitive performance necessary for independent living in old age.

In the study that recruited 103 com- munity-dwelling healthy, older adults, the autors explored the associations of objective measures of cardiorespiratory fitness and physical activity with measures of brain and white matter health [30]. Their findings highlight that engaging in physical activity of various intensity in parallel with avoiding sedentariness are important factors in maintaining white matter health in older age. They propose that physical activity allows keeping white matter under control via cerebrovascular mechanisms, such as preserving higher blood vessel elasticity and wall integrity. Also, they propose an association between light physical activity and white matter integrity in the temporal lobe. There is a speculation that these associations are related to neurotrophic, cerebrovascular, lipid and insulin metabolic mechanisms related to physical activity [30].

\section{MOLECULAR MECHANISMS}

It has been known that brain-derived neurotrophic factor (BDNF) is critically important for neuronal differentiation, synaptic plasticity and neuron survival [31], [32]. Thus, BDNF upregulation is proposed mechanism for the cognitiveenhancement triggered by physical exercise.

Allard, et al.[33] proposed that an increase in aerobic capacity would result in a parallel increase in BDNF levels. They conducted a pilot study designed to analyze exercise-induced BDNF upregulation in the population of African Americans, age 55 years and older, diagnosed with mild cognitive impairment 
who participated in a six-month, supervised program of either stretch (control treatment) or aerobic (experimental treatment) exercise. They examined the effects of Apolipoprotein E (EAPOE) gene $\varepsilon 4$ carrier status on changes in BDNF expression after a standardized exercise program. They identified a relationship between the $\varepsilon 4$ allele and BDNF response to physiologic adaptation which likely impacts the extent of neuroprotective benefit gained from engagement in physical exercise

\section{EXERCISE INTERVENTIONS}

A program of exercise intervention to improve cognition in people with mild to moderate dementia was developed [34]. The program consists of two parts: a supervised part lasting 4 months and an unsupervised one lasting an additional 8 months. The supervised part includes a pre-exercise assessment, twice-weekly exercise classes of appro-

$\sim$ ximately one hour duration (including $\ddot{0} 50$ min of exercise at the target intensity) $\rightarrow$ for 4 months with a target of at least 50 min of unsupervised activity at moderate intensity, to achieve a grand total of $150 \mathrm{~min}$ per week. The exercises classes are a combined aerobic and resistance training schedule, delivered in groups of up to 8 participants. An aerobic exercises consisted of cycling at a low intensity depending upon the initial fitness of the participant. The aerobic challenge then progressed up to $25 \mathrm{~min}$, as well as the duration spent at moderate and high intensity. Progression was in- dividually tailored. The weight lifted was increased, with participants performing 15 repetitions for three weeks into classes and 10 repetitions at a higher weight again at seven weeks. The weight was subsequently increased if the participant was able to perform two additional repetitions with good form, or decreased if the participant could not perform the required number of repetitions. A systematic review concluded that long intervention duration, high exercise intensity and good adherence all appear to be important in obtaining cognitive benefits in people with dementia or mild cognitive impairment [35].

\section{CONCLUSION}

Motoric function and cognition are closely related. Lack of physical activity reduces the natural protective resources for cognition and increases the risk of falls in elderly. As the ageing population increases worldwide, this becomes a growing healthcare problem. Locomotion is sensitive to cognitive decline and can be used as a marker of mild cognitive impairment of dementia. Assessment of motoric functions especially locomotor is a very valuable tool in predicting the onset of dementia. The main interface between physical exercise and cognition is supposed to be hippocampus, and on molecular level BDNF. Structured physical exercise, individually tailored is proven to be of benefit for cognitive functions both in healthy old people and those with cognitive impairments. 
MOTORNE FUNKCIJE

I KOGNICIJA KOD STARIH

OSOBA

\author{
Stevan S. Jovanović ${ }^{1}$ \\ Dragan M. Pavlović ${ }^{2}$
}

1 Visoka zdravstvena škola strukovnih studija u Beogradu, Beograd, Srbija

2 Fakultet za specijalnu edukaciju i rehabilitaciju, Univerzitet u Beogradu, Beograd, Srbija

\section{NAPOMENA}

Ovaj rad je finansiran sredstvima

iz projekta broj 175033 Ministarstva za

nauku i tehnološki razvoj Republike Srbije.

\section{Kratak sadržaj}

Produžetak životnog veka i povećanje udela starijih ljudi u opštoj populaciji postavlja nove zadatke za zdravstvene službe. Jedan od njih je istraživanje i razjašnjavanje odnosa i povezanosti između motorickih i kognitivnih funkcija kod osoba starijeg životnog doba. Tokom procesa starenja odigrava se "osiromašenje" kognitivnih kapaciteta. Mnoge studije ukazuju na postojanje izrazite povezanosti između kognitivnih funkcija i funkcije hoda. Postoji sve više dokaza da opadanje kognitivnih funkcija rezultuje deterioracijom funkcije hoda. Poremećaj funkcije hoda se obično povezuje sa kasnijim stadijumima demencije, međutim, ona može biti narušena i u ranijim stadijumima pa čak i pre nastanka prodromalnog stadijuma tj. blagog kognitivnog poremećaja. Brzina koraka i vremenska i prostorna varijabilnost koraka su glavne karakteristike koje se povezuju sa stepenom pada kognitivnih procesa. Ove karakteristike su motorni fenotip koji reflektuje stepen deterioracije kognitivnog funkcionisanja i koji može biti upotrebljen kao prediktivni pokazatelj nastanka demencija.

Pretpostavlja se da fizička aktivnost obezbeđuje pozitivne efekte na kognitivnom i psiholoskom planu, uključujući prevenciju i poboljšanje depresivnih i anksioznih stanja, da redukuje stres, unapređuje samopouzdanje i konačno, odlaže nastanak procesa opadanja kognitivnih funkcija kod osoba starijeg doba. Prekidi aksonskih puteva i mijelina u beloj masi se smatraju jednim od primarnih mehanizama za nastanak opadanja kognitivnih funkcija tokom procesa starenja. Zbog toga se pretpostavlja da je održavanje strukturalne celovitosti bele mase jedan od ključnih faktora koji doprinose očuvanju viših kognitivnih funkcija koje su neophodne za nezavisno funkcionisanje u starijem životnom dobu. Fizička aktivnost takođe deluje preko cerebrovaskulnih mehanizama kao što su očuvanost elastičnosti i integriteta zidova krvnih sudova.

Osim pomenutog, postoji povezanost između lagane fizičke aktivnosti i integriteta bele mase posebno u temporalnom lobusu. Zaključci pojedinih istraživanja ukazuju na postojanje odnosa između $\varepsilon 4$ genskog alela i brain derived neurotrophic factor (BDNF) odgovora na fiziološku adaptaciju nastalu fizičkim vežbanjem, za koju se pretpostavlja da pozitivno utiče na neuroprotekciju. Neki autori predlažu program fizičkog vežbanja kao kombinaciju aerobnog i treninga sa primenjenim otporom. Motorička funkcija i kognicija su blisko poezani, a redovna fizička aktivnost i vežbanje je važno za održavanje fizičkog i mentalnog zdravlja.

Ključne reči: kretanje, fizička aktivnost, kognicija, starije osobe. 


\section{References}

1. Yeolekar ME,Sukumaran S. Frailty Syndrome: A review. Journal of Association of Physicians India 2014;62(11):34-8.

2. Vallin J.The end of the demographic transition: Relief or concern? Population and Development Review 2002;28(1):105-12.

3. AARP International. Major developments and trends in global aging. United Nations Headquarters 2007;77-9.

4. Pavloviæ DM, Pavloviæ AM. Higher cortical functions. Basics of behavioral neurology and neuropsychology. Belgrade, Serbia:Orion Art 2016.

5. Thomas KM, Hunt RH, Vizueta N, Sommer T, Durston S, Yang Y, Worden MS. Evidence of developmental differences In implicit sequence learning: an fMRI study of children and adults. Journal of Cognitive Neuroscience 2004;16:1339-51.

6. Li KZH, Krampe RT, Bondar A. An Ecological Approach to Studying Aging and Dual-Task Performance. In: Engle RW, et al. Cognitive limitations in aging and psychopathology. New York, NY, USA: Cambridge University Press 2005:190218.

7. Monge ZA, Madden DJ. Linking visual perceptual and cognitive decline in healthy aging: The information degradation hypothesis. Neuroscience \& Biobehavioral Reviews 2016;69:166-73.

8. Kramer A.F, Bherer L, Colcombe S.J, Dong W, Greenough WT. Environmental Influences on Cognitive and Brain Plasticity During Aging. Journal of Gerontology Gerontological Society of America 2004;59(9):940-57.
9. Nutt JG, Marsden CD, Thompson PD. Human walking and higher-level gait disorders, particularly in the elderly. Neurology 1993:43:268-79.

10. Beauchet $O$, Allali G, Berrut G, Hommet C, Dubost V, Assal F. Gait analysis in demented subjects: Interests and perspectives, Neuropsychiatric Disease and Treatment 2008;4(1):155-60.

11. Montero-Odasso M, Verghese J, Beauchet O, Hausdorff JM. Gait and cognition: a complementary approach to understanding brain function and the risk of falling Journal of the American Geriatrics Society 2012;60:2127-36.

12. Sheridan PL, Solomont J, Kowall N, Hausdorff JM. Influence of executive function on locomotor function: divided attention increases gait variability in Alzheimer's disease. Journal of the American Geriatrics Society 2003;51:1633-37.

13. Marquis S, Moore MM, Howieson DB, Sexton M, Payami H, Kaye JA, Camicoli R. Independent predictors of Cognitive Decline in Healthy Elderly Persons. Archives of Neurology 2002;59(4):601-06.

14. León I, Tascón L, Cimadevilla JM. Research report: Age and gender-related differences in a spatial memory task in humans. Behavioural Brain Research 2016;306:8-12.

15. Olivier G, Allali B, Montero-Odasso M, Sejdic E, Fantino B, Annweiler C. Motor Phenotype of Cognitive Decline in Performance among Community-Dwellers without Dementia: Population-Based Study and Meta-Analysis. Preuzeto nov. 2016. Dostupno na: PLoS ONE | www.plosone.org June 2014 | Volume 9 | Issue 6 | e99318. 
16. Verghese J, Wang C, Lipton RB, Holtzer R. Motoric cognitive risk syndrome and the risk of dementia. The Journals of Gerontology A Biological Sciences and Medical Sciences 2013;68:412-18.

17. Zimmerman ME, Lipton RB, Pan JW, Hetherington HP, Verghese J. MRI- and MRSderived hippocampal correlates of quantitative locomotor function in older adults. Brain Research 2009;1291:73-81.

18. Montero-Odasso $\mathrm{M}$, Bergman $\mathrm{H}$, Phillips $\mathrm{NA}$, Wong $\mathrm{CH}$, Souria N. Dual-tasking and gait in people with mild cognitive impairment. The effect of working memory. BioMed Central Geriatrics 2009;9(1):41.

19. Verghese J, Robbins M, Holtzer R, Zimmerman M, Wang C, Xue X, Lipton RB. Gait dysfunction and mild cognitive impairment syndromes. Journal of the American Geriatrics Society 2008;56:1244-51.

20. Montero-Odasso M, Oteng-Amoako A, Speechley M, Gopaul K, Beauchet O, Annweiler C, Muir-Hunter SW. The Motor Signature of Mild Cognitive Impairment: Results From the Gait and Brain Study. The Journals of Gerontology A Biological Sciences and Medical Sciences 2014;69(11):1415-21.

21. Burgess N, Maguire AE, O'Keefe J. The Human Hippocampus and Spatial and Episodic Memory Neuron 2002;35(4):62541.

22. Liu-Ambrose T, Ashe MC, Graf P, Beattie $\mathrm{BL}$, Khan KM. Increased risk of falling in community-dwelling older women with mild cognitive impairment. Physical Therapy 2008;88:1482-91.

23. Kaliman P, Párrizas M, Lalanza JF, Camins A, Escorihuela RM, Pallàs M. Neurophysiological and epigenetic effects of physical exercise on the aging process. Ageing Research Reviews 2011;10(4)475-86.
24. Fotuhi M, Do D, Clifford J. Modifiable factors that alter the size of the hippocampus with aging, Nature Reviews Neurology 2012;8:189-202.

25. Erickson KI, Prakash RS. Voss MW, Chaddock L, Hu L, Morris KS, et al. Aerobic fitness is associated with hippocampal volume and elderly humans, Hippocampus 2009;19(10):1030-39.

26. Erickson K, Voss MW, Prakash RS, Basak C, Szabo A, Chaddock L, et al. Exercise training increases size of hippocampus and improves memory, Proceedings of the National Academy of Sciences of the United States of America 2011;108:3017-22

27. Haight TJ, Bryan RN, Erus G, Davatzikos C, Jacobs DR, D'Esposito M, et al. Vascular risk factors, cerebrovascular reactivity, and the default-mode brain network Neuroimage 2015;115:7-16.

28. Madden DJ, Bennett IJ, Burzynska A, Potter GG, Chen N-K, Song AW. Diffusion tensor imaging of cerebral white matter integrity in cognitive aging. Biochimia et Biophysica Acta 2012;1822:386400.

29. Raz N, Rodrigue KM. Differential aging of the brain: patterns, cognitive correlates and modifiers. Neurosci Biobehav Rev 2006;30:730-48.

30. Burzynska AZ, Chaddock-Heyman L, Voss MW, WongCN., Gothe NP, Olson EA, et al. Physical activity and cardiorespiratory fitness are beneficial for white matter in low-fit older adults. A Peer-Reviewed Open Acess Journal 2014;9(9):e107413. 
31. Mariga A, Zavadil J, Ginsberg S.D, Chao M.V. Withdrawal of BDNF from hippocampal cultures leads to changes in genes involved in synaptic function. Developmental Neurobiology 2015;75:173-92.

32. Vilar M, Mira H. Regulation of neurogenesis by neurotrophins during adulthood: expected and unexpected roles. Frontiers in Neuroscience 2016;10:26.

33. Allard JS, Ntekim O, Johnson SP, Ngwa JS, Bond V, Pinder D, et al. APOE impacts up-regulation of brain-derived neurotrophic factor after a six-month stretch and aerobic exercise intervention in mild cognitively impaired elderly African Americans: A pilot study. Experimental Gerontology 2017;87:129-36.

34. Brown D, Spanjers K, Atherton N, Lowe J, Stonehewer L, Bridle C, et al. Development of an exercise intervention to improve cognition in people with mild to moderate dementia: Dementia And Physical Activity (DAPA) Trial, registration ISRCTN32612072 Physiotherapy 2015;101(2):126-34.
35. Ohman H, Savikko N, Strandberg TE, Pitkala KH. Effect of physical exercise on cognitive performance in older adults with mild cognitive impairment or dementia: a systematic review. Dementia and Geriatric Cognitive Disorders 2014;38(56):347-65.
Dragan M. Pavlović
Faculty for special education and rehabilitation, University of Belgrade Visokog Stevana 2, 11000 Belgrade, Serbia, Email: dpavlovic53@hotmail.com

